\title{
POLITICAL VIOLENCE AND VOLATILITY IN INTERNATIONAL TOURIST ARRIVALS: THE CASE OF SRI LANKA
}

\author{
SRIYANTHA FERNANDO, JAYATILLEKE S. BANDARA, \\ SUSANTHA LIYANAARACHCH, \\ RUWAN JAYATHILAKA, AND CHRISTINE SMITH \\ Department of Accounting, Finance and Economics, \\ Nathan Campus Griffith University, Nathan, Queensland, Australia
}

\begin{abstract}
In recent years, a growing body of literature has emerged exploring the link between dramatic fluctuations in tourist arrivals to particular destinations and events such as political violence and financial shocks. Sri Lanka is one such destination that provides a fascinating case study of this link. That is, international tourist arrivals to Sri Lanka have experienced notable fluctuations during the nearly three decades of civil war, particularly between 1983 and 2009. For the first time, an attempt is made in this study to model the conditional mean and conditional variance of the logarithm of monthly tourist arrivals to Sri Lanka. The results reveal a significant seasonal effect in tourist arrivals to Sri Lanka. First, the study demonstrates the existence of a large volatility in monthly tourist arrivals into Sri Lanka from 1978, stemming from the negative publicity in the print and electronic media and the travel warnings issued by Western countries relating to in-country conflict. Furthermore, the results suggest that major war-related incidents are strong enough to reduce the tourist arrival numbers by $5.2 \%$ per month compared to a period when peace is restored in the country.
\end{abstract}

Key words: Tourist arrivals; Peace; Volatility; Autorregressive conditional heteroskedasticity (ARCH); Sri Lanka

Introduction

Tourism can be defined as travel for recreational, leisure, or business purposes. The United Nations World Tourism Organization (UNWTO) defines a tourist as "any person who travels to a country other than that in which he/she has his/her usual residence, but outside his/her usual environment for a period not exceeding 12 months and whose main purpose of visit is other than the exercise of an activity remunerated from within the country visited" (Sri Lanka Tourism Development Authority [SLTDA], 2010, p. 63). Given the main objective of relaxing and enjoying an uninterrupted holiday in the visited country of choice, it is a well-recognized fact that international tourists are very sensitive to 
war, political violence, and criminal activities. This relationship between tourism and war and terrorism and political stability is well explored within the literature (see Pizam \& Mansfeld, 1996; Sevil, 1998). Particularly among tourism analysts, there is a widespread view that international visitors are very concerned about their personal safety, and thus international tourism can only thrive under peaceful conditions (Hitchcock, King, \& Parnwell, 1993). As Neumayer (2004) points out, "tourists are only willing to travel to foreign places in mass numbers if their journey and their stay are safe and shielded from events that threaten a joyous holiday experience” (pp. 259-260). Continuous political violence, prolonged wars, and suicide bombings in popular tourist centers can subsequently lead international tourists to choose alternate destinations (Bhanugopan, 2001). Furthermore, Western governments tend to issue travel warnings to protect their citizens when political violence and criminal activities are taking place in popular tourist destinations. It is well documented that wars and political violence have detrimental effects on economic growth, particularly on the tourism sector (see Murdoch \& Sandler, 2002; Neumayer, 2004). According to this body of literature, creating a peaceful environment and political stability in a country like Sri Lanka is an important precondition to accelerate economic growth and inclusive economic development via tourism during the postwar period.

In addition to this work, there is another branch of tourism literature that focuses on volatility in international tourist arrivals. This relatively new body of research emphasizes the importance of examining the volatility in tourist arrivals with regard to policy and decision making in both the public and private sectors and future tourism planning (see Chan, Lim, \& McAleer, 2005; Shareef \& McAleer, 2005). To explore this association, Sri Lanka provides an opportunity for an excellent case study. It is well known that Sri Lanka has experienced political violence since the late 1970s, including war and terrorist attacks. This political violence was particularly strong from 1983 up until the end of war in May 2009. As a result of the end of war, Sri Lanka is currently experiencing a tourism boom, and revenue from this boom has become a main source of foreign exchange earnings that help to cushion the current balance of payment crisis in Sri Lanka.
The Sri Lankan government therefore believes that international tourism can play a crucial role in the postwar development of Sri Lanka (Ministry of Economic Development, 2011). Understanding the volatility of tourism demand is vital in terms of planning and making strategic decisions by both the public and private sectors for future development in the tourism sector.

Although the Sri Lankan tourism sector has been growing since 1967, it has experienced significant fluctuations due to political violence (Fernando, Bandara, \& Smith, 2012). Despite its importance in the Sri Lankan economy in terms of contribution to GDP, employment generation and foreign exchange earnings, there has not been much attention on the tourism sector with the exception of a small number of studies (Bandara, 1997; Fernando et al., 2012; Gamage, 1978; Gamage, Shaw, \& Ihalanayake, 1997; O’Hare \& Barrett, 1994; Selvanathan, 2006; Tisdell \& Bandara, 2005; Wickremasinghe \& Ihalanayake, 2006). These studies have been mainly qualitative in nature, with the exception of the studies of Selvanathan (2006) and Wickramasinghe and Ihalanayake (2006). Whereas Selvanathan analyzed factors that determine international tourist arrivals to Sri Lanka, Wickramasinghe and Ihalanayake attempted to examine the causal relationship between tourism and economic growth in Sri Lanka.

Although international tourist arrivals to Sri Lanka have experienced dramatic fluctuations during the separatist war and a number of peace episodes during the period 1983-2009 (for more details, see Fernando et al., 2012), no systematic study has been carried out to examine the volatility that affects decision making and future planning of tourism. Given this, the purpose of the current article is to analyze the conditional variance or volatility in international tourist arrivals to Sri Lanka, focusing particularly on the period of nearly three decades of separatist war that included political violence and terrorist attacks. Such an analysis is useful for designing development and management strategies for the tourism sector that is expected to play a significant role in postwar development in Sri Lanka.

The rest of this article is organized as follows. The following sections describe the main features of inbound tourism in Sri Lanka from a historical perspective using annual data and examine more detailed trends and fluctuations using monthly 
tourism data. The methodology used in the study is presented and the results of the study are analyzed. The final section summarizes the article and presents concluding remarks.

\section{Historical Perspective of Tourism in Sri Lanka}

In this section, we provide a brief overview of the historical evolution of international tourism in Sri Lanka in the context of political violence and fluctuations in tourist arrivals using annual data (for a detailed discussion on the historical evolution of the tourism industry in Sri Lanka, see Fernando et al., 2012).In the period immediately following the attainment of independence from the British in 1948, Sri Lanka did not focus much on international tourism, and tourism was subsequently not considered as a main component of the development strategy. As result of this, the number of international tourist arrivals to Sri Lanka was rather insignificant prior to 1967. International tourist arrivals to Sri Lanka did, however, expand rapidly after 1967 following the establishment of the Sri Lanka Tourist Board and the government's new tourism policy initiatives. As a result of this new policy enthusiasm, the period 1967-1976 witnessed an average annual increase of $19 \%$ in the total overseas visitors to Sri Lanka. This was despite the government's implementing a restrictive trade and exchange rate policy regime. After the introduction of the trade and exchange rate liberalization package in 1977, the total number of tourist arrivals to Sri Lanka increased further by an annual rate of $23 \%$ during the period 1977-1982.

In the period between gaining independence and the early 1980s, there was a phase of political stability and a well-established democracy in Sri Lanka (with an exception of a brief period of youth uprising in 1971 in which more than 10,000 youth were killed). The situation changed dramatically, however, with the eruption of well-known ethnic riots in 1983 and the beginning of the separatist war between the Sri Lankan security forces and the Liberation Tigers of Tamil Ealam (LTTE, commonly known as the Tamil Tigers). Following the ethnic riots in 1983, Sri Lanka experienced three decades of violence and unrest with a number of relatively short peace episodes. In addition to the separatist war between Sri Lankan security forces and the
LTTE in the North and East of the country, there was another youth uprising in the South of the country during the period 1987-1989. During this period Sri Lanka experienced an unprecedented level of violence, death, and destruction, and tourist arrivals to Sri Lanka declined rapidly (see Fig. 1). The "twin wars" in the late 1980s also inflicted a significant cost to the Sri Lankan economy, most notably within the tourism sector (Abeyratne, 2004). Figure 1 summarizes the fluctuations and volatility in tourist arrivals in Sri Lanka since 1983.

In addition to the low arrival rate of overseas visitors, Sri Lankan tourism has also suffered fluctuations in tourist arrivals. Despite a number of peace episodes in 1987, 1991, 1994, and 2002-2006, these fluctuations have had the effect of creating volatility. A right-of-center and market-friendly liberal government, led by the United National Party (UNP), ruled the country from 1977 to 1994 for 17 years. During this period, democracy in Sri Lanka was eroded and government institutions were politicized as a result of the presidential system, which was introduced with constitutional changes in 1978. Parliamentary and presidential elections were held under increasingly violent environments. During this period of the UNP regime, Sri Lanka witnessed a worsening level of political violence. A new leftof-center government then came to power in 1994 led by the People Alliance (PA). Through encouraging open economic policies, a strategy of this new government was to attract increased tourist arrivals. Following the very low level of tourist arrivals to Sri Lanka in the late 1980s and the early 1990s, the arrival rate bounced back. This was assisted in part by the initiation of peace talks between the LTTE and the newly elected government, which held the promise of bringing peace and elimination of violence. However, similar to previous attempts of peace talks in 1987and 1991, the 1994 peace talks collapsed and the war started again in earnest at the end of 1994. According to the Sri Lanka Tourist Board (SLTDA, 2010), 380,769 tourists arrived in Sri Lanka on average per annum between 1994 and 2002 with some fluctuations within this period. Tourist arrivals to Sri Lanka bounced back in 2002 with another round of peace talks and a cease-fire agreement (CFA) between the LTTE and the Sri Lankan government, brokered by Norway with the backing of the international community. Unofficial 


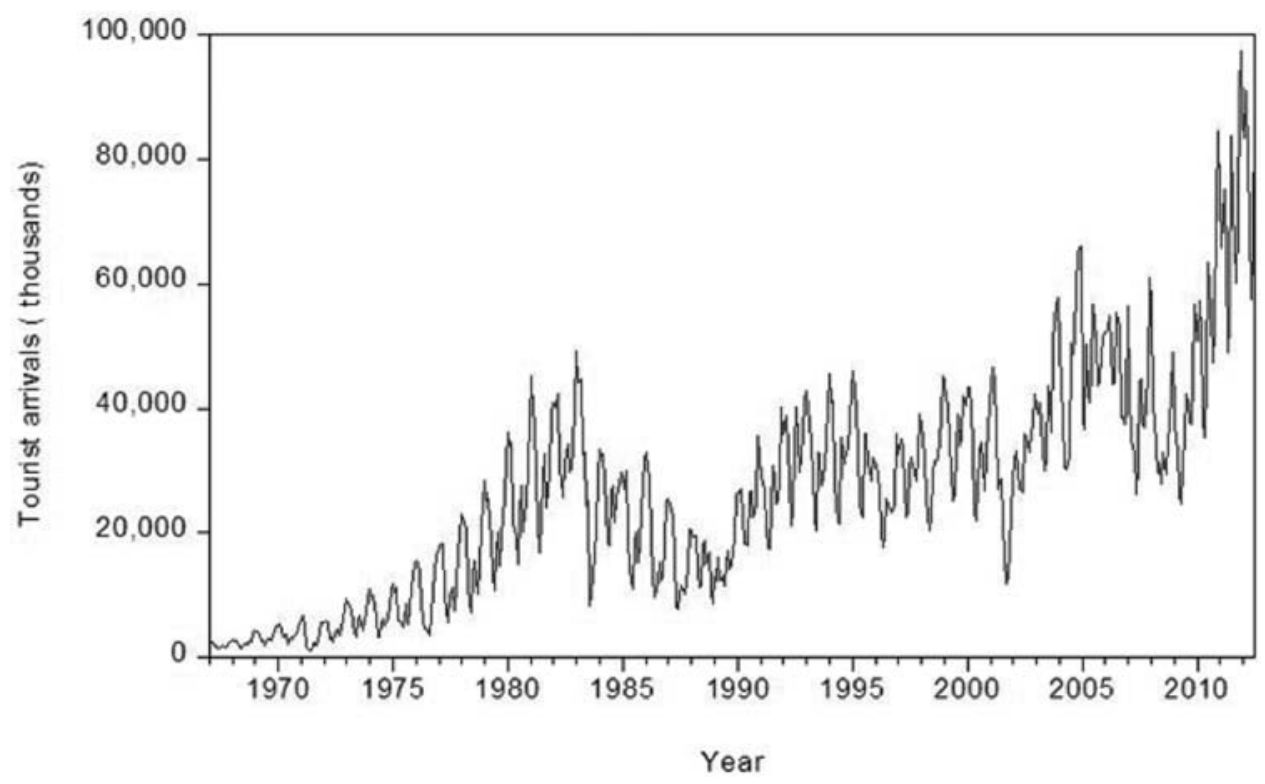

Figure 1. Trend of monthly tourist arrivals in Sri Lanka, January 1967-July 2012. Source: Based on Sri Lanka Tourist Board, various annual reports.

war started again in 2006, however, during the period of the CFA, and tourist arrivals to Sri Lanka decreased $11.7 \%$ in 2007 and a further $11.2 \%$ in 2008 (see Fig. 1). The negative travel advisories issued by Western governments and the uncertain security situation and violence with regular suicide bombings in the capital Colombo played a major contribution to the significant drop in arrivals between 2007 and 2008.

Sri Lanka's nearly three decades of separatist war ended in May 2009 with the defeat of the LTTE by the Sri Lankan security forces. This led to a postwar tourism boom with the number of tourist arrivals creating new records in 2010 and 2011 (e.g., tourist arrivals to Sri Lanka increased to 855,975 in 2011). The arrival numbers have nearly doubled within 2 years (when compared with 447,890 tourist arrivals in 2009), and they are now expected to rise further in coming years.

Upon recognizing the key role that the tourism sector can play in postwar development, the Sri Lankan government has launched a Tourism Development Strategy (TDS) with a 5-year master plan for 2011-2016 (for more details, see Ministry of Economic Development, 2011). Under this tourism plan, the Sri Lankan government is expecting to attract 2.5 million tourists annually by 2016 and increase tourism-related foreign exchange earnings from \$501 million in 2010 to \$2.75 billion. Other targets in the TDS include doubling the current hotel room capacity from 22,745 to 45,000 and increasing tourism-related employment from the current level of 125,000 to 500,000 by 2016 .

\section{Data}

Following the above brief historical overview on tourism in Sri Lanka, we now move on to examine the volatility in international tourist arrivals to Sri Lanka precipitated by political violence and the separatist war. This will be achieved using a data set that comprises monthly international tourist arrivals from January 1967 to July 2012. For the purpose of our study, this data set was assembled using various publications of the Sri Lanka Tourist Board and the Central Bank of Sri Lanka. To our knowledge, this is the most comprehensive monthly tourist arrival data set created for Sri Lankan tourism to date. The data set comprises 547 observations.

Figure 2 plots the first difference of logarithm of monthly tourist arrivals to Sri Lanka. At the beginning of the monitored period, an increase in total number 


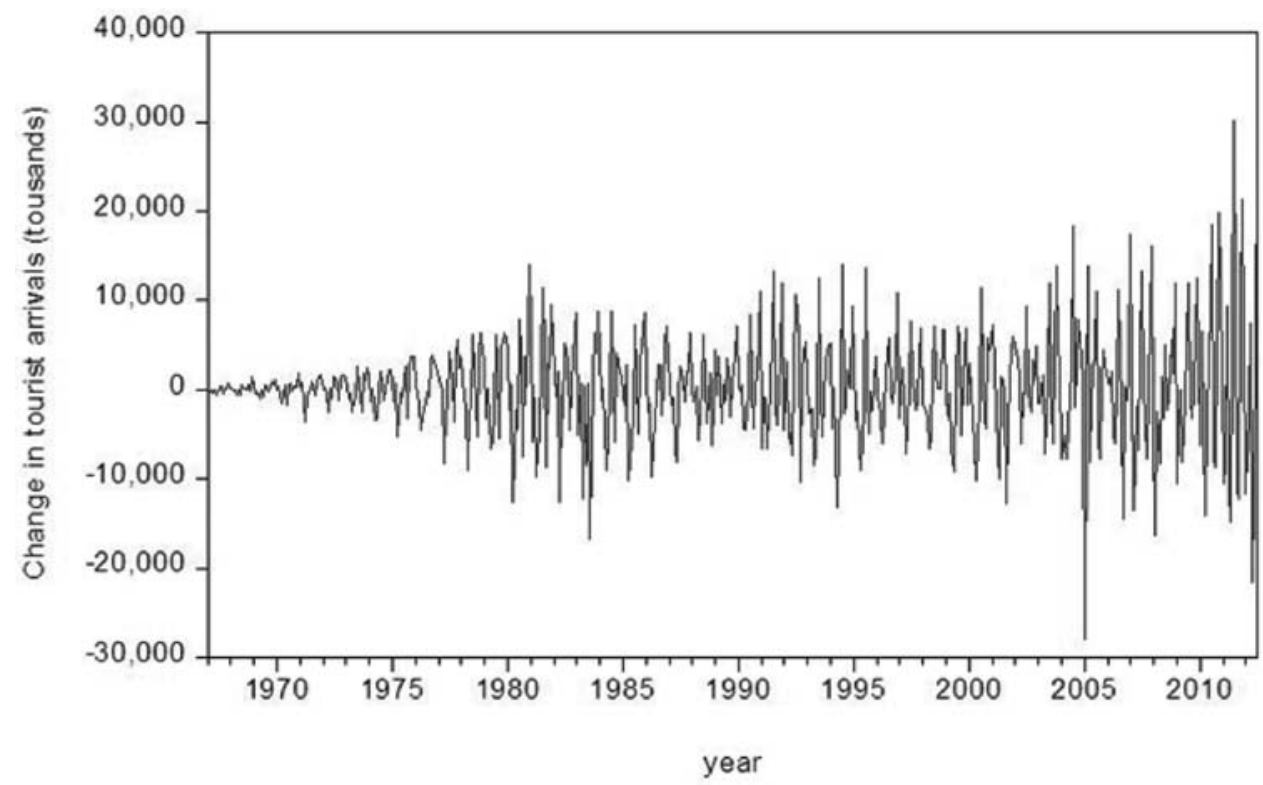

Figure 2. First difference of monthly tourist arrivals in Sri Lanka, January 1967-July 2012. Source: Based on Sri Lanka Tourist Board, various annual reports.

of tourist arrivals is recorded, with three noticeable deeper drops observed in the months of April 1971, August 1983, and August 2005. Furthermore, as seen in Figure 2, the numbers of tourist arrivals between 1983 and 2012 have proven to be highly volatile.

This finding is consistent with the general view in the tourism literature. As Neumayer (2004) points out, "events of political violence are likely to affect tourism both contemporaneously and with lagged effects" (p. 261). He further points out that "because tourists are sensitive to the negative image of tourist destination, events of violence can affect a tourist destination, and events of violence can affect long after the event has passed and stability has, in effect, been restored"(p. 262).

The time series also indicates a considerably pronounced seasonality with the focus of intensity of total arrivals in some months, especially in July and December. This is seen by a simple visual inspection of the natural logarithm of the total arrivals in Sri Lanka as shown in Figure 3.

\section{Methodology}

In analyzing demand for tourism, a number of statistical and econometric models have been used in the literature. Song and $\mathrm{Li}$ (2008) have reviewed a large number of published studies on tourism demand modeling and forecasting since 2000. These models mainly include structural equations and time series techniques (Sinclair \& Stabler, 1997; Song \& Witt, 1999), VAR models, and the co-integration technique (Sergo, Tomcic, \& Poropat, 2005) and AIDS models (De Mello, Pack, \& Sinclair, 2002; Syriopoulos \& Sinclair, 1993; White, 1985).

Tourism demand can be measured by either using the number of inbound tourist arrivals or using foreign exchange receipts from international tourism (Neumayer, 2004). Many studies have used the number of tourist arrivals to measure tourism demand. These studies have mainly forecasted the changes in the number of tourists over time and usually consider a random term that incorporates all the unknown effects on tourism demand over time. Until recently, the variability in the random component of tourism demand had not been of major concern to tourism researchers (as often is in financial or other macroeconomics research). That is, apart from the standard approaches of testing for heteroskedasticity and/or serial correlation (Sergo, Poropat, \& Grzinic, 2010). Heteroskedastic and/ 


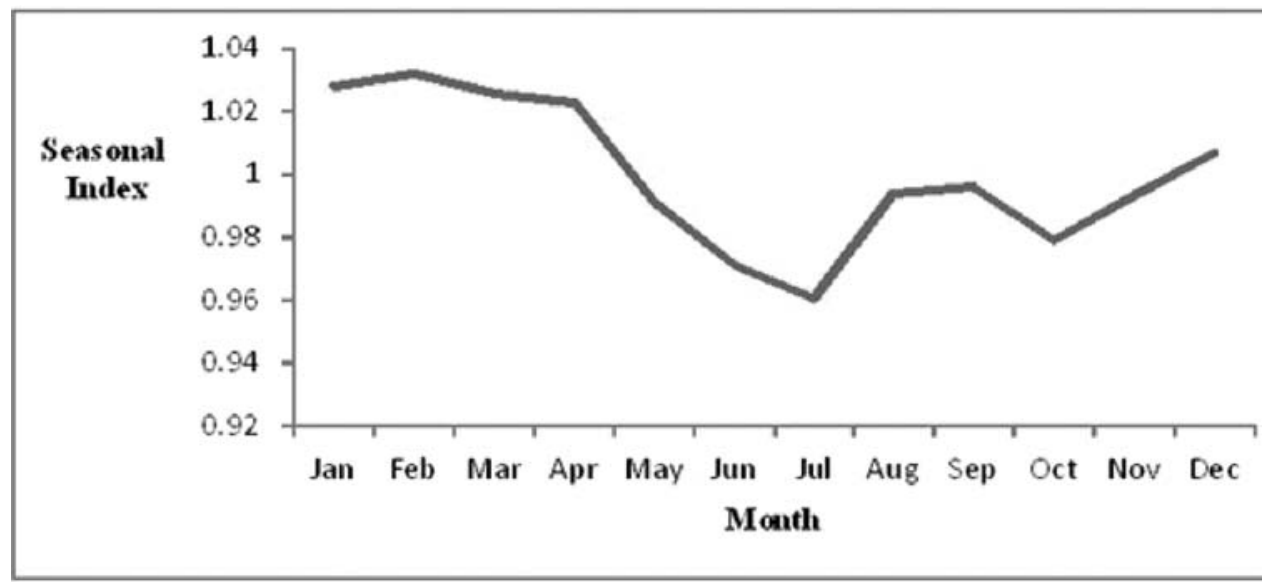

Figure 3. Monthly seasonal indices for Sri Lankan tourism demand. Source: Based on Sri Lanka Tourist Board, various annual reports.

or serially correlated errors can lead to imprecise estimates of tourism demand, thereby reducing the forecasting performance of the models (Hoti, Leon, \& McAleer, 2005). Several studies have found that tourism demand data exhibit volatility (Shareef \& McAleer, 2005).

Although the Sri Lankan separatist war was well recognized as one of Asia's longest running wars and the negative impact of the war on the Sri Lankan tourism sector is easy to observe, there has not been any serious attempt to quantify the impact of war on tourism. This is with the exception of Selvanathan (2006). Using an econometric model, Selvanathan found that there was a significant decline in tourist arrivals due to war and that the Sri Lankan tourism is sensitive to the exchange rate. In this study, we attempt to investigate the link between war, peace, and tourism and other relevant variables further by looking at volatility.

\section{Model Specification}

As pointed out by McAleer and Divino (2008) and Chang, McAleer, and Slottje (2009), the generalized autoregressive conditional heteroskedasticity (GARCH) model (proposed by Engle, 1982) can be used to explain time-varying conditional variances in financial and tourism data series. The generalized GARCH(p,q) model proposed by Bollerslev (1986) can be used "when the time-varying conditional variance has both autoregressive and moving average components” (Chang et al., 2009).This technique has widely been used to estimate conditional volatility using monthly international tourism arrival data in recent years (see, e.g., Chan et al., 2005; Hoti et al., 2005; Shareef \& McAleer, 2005, 2007, 2008; Divino \& McAleer, 2008). Following this literature, we use the GARCH model introduced by Bollerslev (1986) to analyze Sri Lankan monthly international tourism arrival data and to capture the volatility characteristics inherent within it.

In order to estimate the impact of some important variables on the number of tourist arrivals, the following model is used as the mean equation:

$$
\begin{aligned}
\ln y_{t} & =\varphi_{0}+\varphi_{1} \ln \mathrm{EXR}_{t}+\varphi_{2} \ln \mathrm{TPI}_{t} \\
& +\varphi_{3} \mathrm{WAR}+\sum_{j=12}^{12} \beta_{j} D_{j}+\varepsilon_{t}
\end{aligned}
$$

where ln $y$ denotes the natural logarithm of tourist arrivals to Sri Lanka, ln EXR and ln TPI are the natural logarithm of exchange rate and tourism price index, respectively, and WAR is a dummy variable equal to 1 if the country was in the peak of the civil war and 0 otherwise. After considering war-related incidence, 1967-1983, 1992-1997, 2000-2001, and 2003-2007 periods were considered as peaceful time periods for which the dummy variable takes the value 0 , with the value 1 assigned to other years. In 
addition, dummy variables were included to capture the effect of seasonal variation on tourism demand. There are 11 dummy variables included ranging from $D_{2}$ to $D_{12}$ where $D_{2}=1$ if the month is February and 0 otherwise. Likewise, the other seasonal dummy variables represent in turn each month except for January, which is considered as the base category. Inclusion of these seasonal dummy variables within the model acts to remove the seasonal fluctuations in the data. This enables us to be able to more easily isolate the impact of other events on tourist arrivals.

The GARCH(p,q) is used as the model for conditional variance of $\varepsilon_{t}$ generated by the mean equation based on Eq. (1).

$$
\sigma_{t}^{2}=\sigma_{0}+\sum a_{i} \varepsilon_{t-1}^{2}+\sum \beta_{j} \sigma_{t-1}^{2}+\varphi \mathrm{WAR}
$$

The conditional variance is a function of four terms, namely, $\sigma_{0}, \varepsilon_{t-1}^{2}, \sigma_{t-1}^{2}$, and WAR. Among the two terms $\varepsilon_{t-1}^{2}$ and $\sigma_{t-1}^{2}$, the first refers to the ARCH term and the second captures the previous period forecast variance (hence the conditional variance). The variable WAR, as defined above, captures the impact of civil war on tourism volatility. If WAR $=1$, it means that the tourism sector is facing a negative impact, and 0 means no such impact from the civil war. According to the GARCH model, $\sigma_{0}>0, \alpha_{i} \geq 0, \beta_{i} \geq 0(i, \ldots, p ; j=1, \ldots, q)$ are the necessary conditions to generate a positive number for the conditional variance. The sum of coefficients $\left(\sum_{i=1}^{p} \alpha_{i}+\sum_{j=1}^{q} \beta_{i}+\varphi<1\right)$ of the GARCH models should be less than 1 to guarantee that the conditional variance, $\sigma_{i}^{2}$, is stationary.

\section{Results}

The maximum likelihood procedure is used to estimate the parameters of the above model using a data set collected from different sources in Sri Lanka covering the sample of monthly data from 1967 to 2012. Total number of tourist arrivals was taken from the SLTDA and annual reports of the central bank of Sri Lanka were used to obtain data on the exchange rate and the tourism price index. Table 1 shows the estimated parameters of the conditional mean equations and conditional variance equations according to the $\operatorname{GARCH}(1,1)$ volatility model.
Table 1

Regression Results to Test the Seasonal Unit Root Using HEGY Procedure

\begin{tabular}{llcl}
\hline $\begin{array}{l}\text { Null } \\
\text { Hypotheses }\end{array}$ & $\begin{array}{c}\text { Estimated } \\
\text { Statistics }\end{array}$ & $\begin{array}{c}\text { Null } \\
\text { Hypotheses }\end{array}$ & $\begin{array}{c}\text { Estimated } \\
\text { Statistics }\end{array}$ \\
\hline$\pi_{1}=0$ & -0.1470 & $\pi_{10}=0$ & $-6.2616^{* * * *}$ \\
$\pi_{2}=0$ & $-3.7684^{* * *}$ & $\pi_{11}=0$ & -0.4821 \\
$\pi_{3}=0$ & -0.8769 & $\pi_{12}=0$ & $-3.2725^{* * *}$ \\
$\pi_{4}=0$ & -0.6797 & $\pi_{3}=\pi_{4}=0$ & 0.6407 \\
$\pi_{5}=0$ & $-4.6019^{* * *}$ & $\pi_{5}=\pi_{6}=0$ & $12.432^{* * *}$ \\
$\pi_{6}=0$ & $-4.9577^{* * *}$ & $\pi_{7}=\pi_{8}=0$ & $25.077^{* * *}$ \\
$\pi_{7}=0$ & 0.7203 & $\pi_{9}=\pi_{10}=0$ & $8.5444^{* * *}$ \\
$\pi_{8}=0$ & $-3.3578^{* * *}$ & $\pi_{11}=\pi_{12}=0$ & $16.2919^{* * *}$ \\
$\pi_{9}=0$ & $-5.8547^{* * *}$ & & \\
\hline
\end{tabular}

Source: Authors' calculations. $p<0.05$. *** $p<0.01$.

The error term $\hat{\varepsilon}_{t}$ obtained from OLS estimation of the mean Eq. (1) and the estimated volatility, $\hat{\varepsilon}_{t}^{2}$, are shown in Figures 4 and 5. The error term of the regression does not satisfy the condition of independent and identically distributed random variables, with a mean of 0 , a variance of 1 , and $\varepsilon_{t}$ independent of $\left\{y_{t-k}, k \geq 1\right\}$ for all $t$. In other words, the error term in the mean equation does not have the property of homoskedasticity in variance that shows autocorrelation in the error variance. This indicates that the error term has ARCH effects.

Changes in the variance of shocks to tourism demand over time are often called conditional or stochastic volatility. As a result of many factors that can affect the tourism market, it is clear that shocks to demand may not have the same variability over time. In the case of tourism, volatility may be present due to various unexpected factors that can affect tourist decisions, such as the severity of war, changes in disposable income, advertising campaigns, oil price shock, wealth effects, and other random events.

Figure 5 shows volatility clustering phenomenon in which other large aftershocks continuously follow a larger shock. In addition, a large variation in $\varepsilon_{t}$ was noted during the period after 1978 to the present period. This reflects the existence of a large volatility in monthly tourist arrivals into Sri Lanka resulting from negative publicity in the print and electronic media and travel warnings issued by Western countries relating to war and peace in the country. These periods were clearly identified 


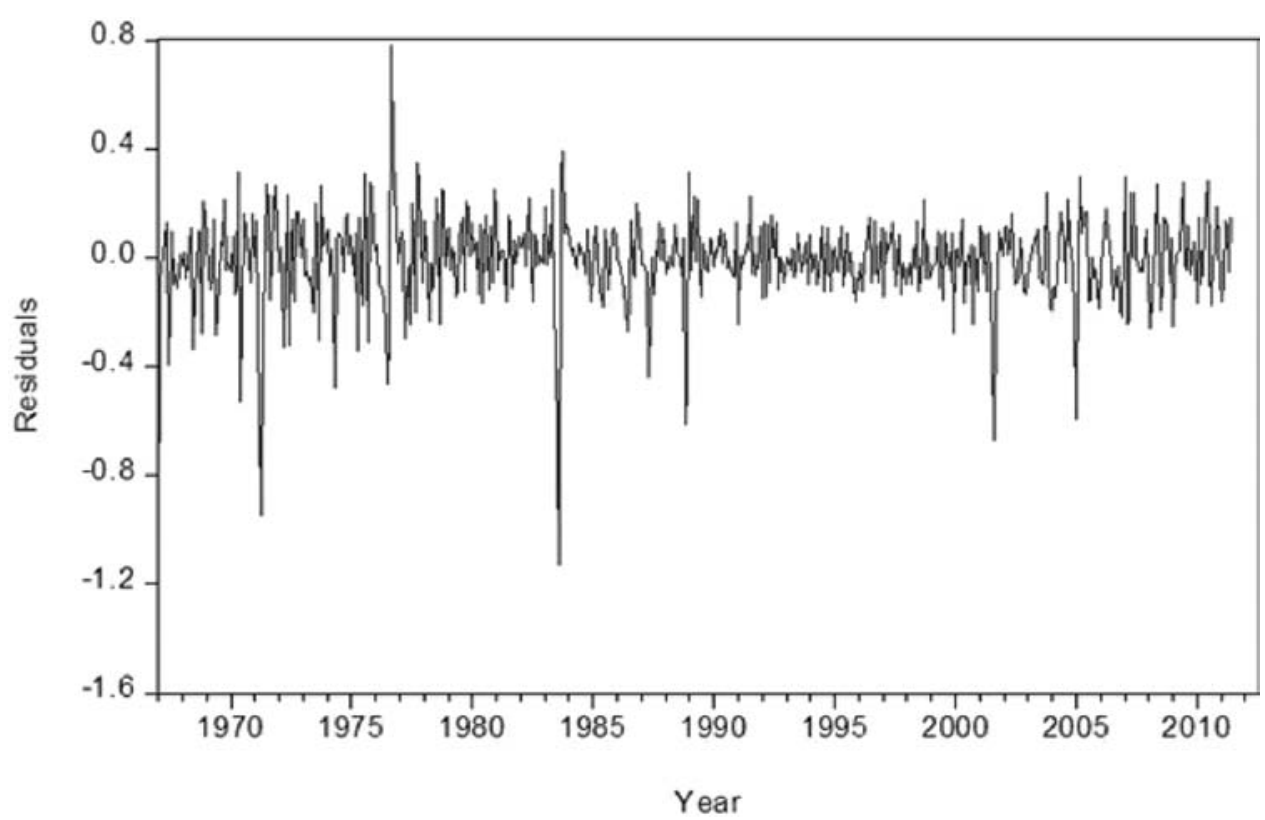

Figure 4. Time series plot of OLS error term $\varepsilon_{t}$. Source: Based on Sri Lanka Tourist Board, various annual reports.

when the war was in its peak as well as when major attacks were carried out by the LTTE on Sri Lanka's important economic and political targets in Colombo (the main economic and political center of the country).
All the variables used in the estimates are tested for unit roots using the augmented Dickey-Fuller test. Unit root tests imply that all the variables integrated in order one. The seasonal unit root test is performed at different seasonal frequencies using

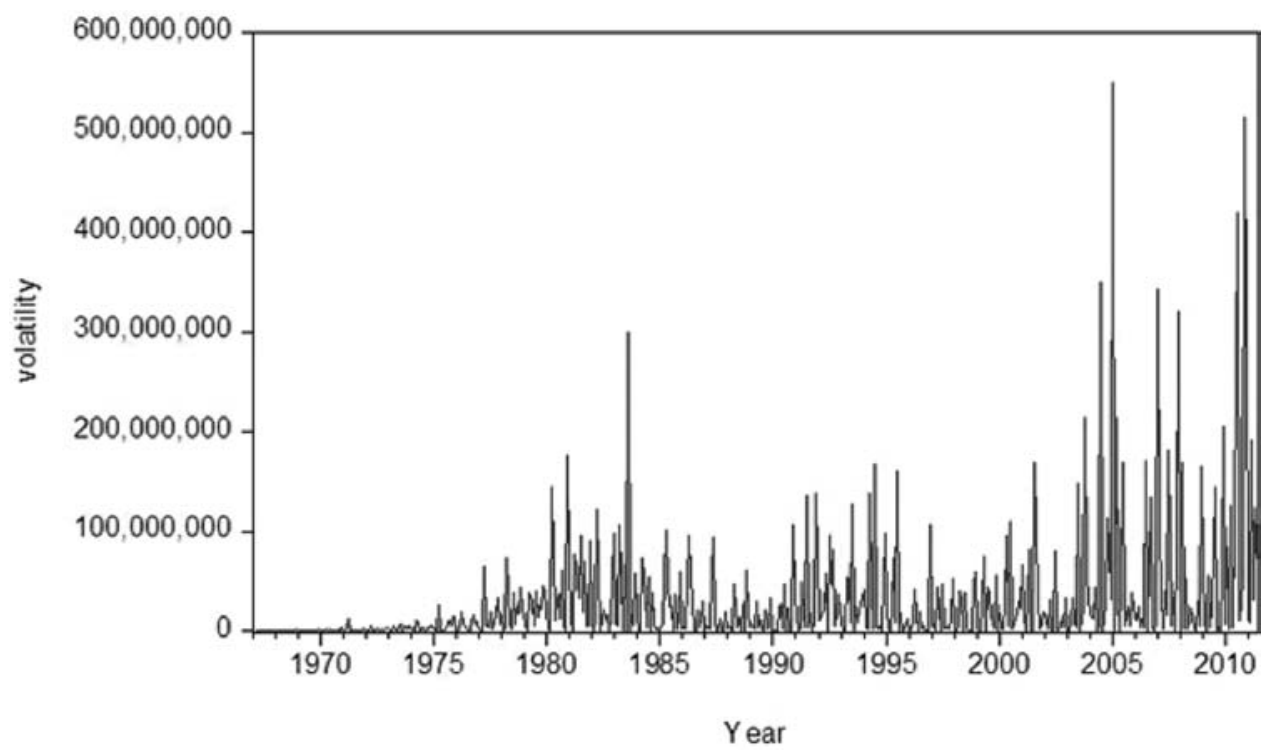

Figure 5. Volatility of tourism demand for Sri Lanka. Source: Based on Sri Lanka Tourist Board, various annual reports. 
the extended Hylleberg, Engle, Granger, and Yoo (1990) (henceforth, HEGY) procedure for the case of monthly data used in this study. The HEGY test is conducted by estimating the following regression,

$$
\begin{aligned}
\varphi(L)^{*} Y 13_{t} & =\alpha_{0}+\alpha_{1} t+\sum_{k=2}^{12} \alpha_{k} D_{k t} \\
& +\sum_{k=1}^{12} \pi_{k} Y k_{t-1}+\varepsilon_{t}
\end{aligned}
$$

where $Y k_{t}(k=1,2, \ldots, 13)$ are auxiliary variables obtained by appropriately filtering the variable under study. The $\varphi(L)^{*}$ polynomial is a remainder with roots outside the unit circle that allows the augmentation necessary to whiten the errors in the estimation of the above equation.

After estimating the above regression using the OLS, tests are conducted for $\pi_{i}$ in each frequency and joint test hypothesis to determine the presence of unit roots and seasonal unit roots (refer to Table 1). In this case, the data do not reject the presence of unit roots at seasonal frequencies of 2, 3, 8, 9 , and 12 including the existence of a unit root at the zero frequency. This means that tourist arrival is nonstationary both at seasonal and nonseasonal frequencies. These results further imply that there is no deterministic cycle at these frequencies but there is a stochastic cycle.

We begin our discussion with the results obtained in the mean equation regression model. As shown in Table 2, ln EXR and WAR, are significant at the $1 \%$ significance level. This positive relationship between $\ln$ EXR and tourist arrivals indicates that Sri Lanka will be more attractive for incoming tourists when the Sri Lankan rupee depreciates against US dollar. The variable that was created to capture the effects of war on tourist arrival indicates a negative coefficient, which is consistent with expectations, in particular the fact that tourist arrivals will on average be $5.2 \%$ lower when the war is in the peak. What can thus be seen from this is that a major warrelated incident is strong enough to reduce the tourist arrival by $5.2 \%$ per month compared to a period when peace is restored in the country. Although the tourism price index was not statistically significant,
Table 2

The Estimated Results for Volatility Model

\begin{tabular}{lcr}
\hline Variable & Coefficient & z Statistic \\
\hline C & $0.631^{* * *}$ & 3.668 \\
WAR & $-0.052^{* * *}$ & -3.050 \\
LEXR & $0.036^{* * *}$ & 4.039 \\
$D_{2}$ & -0.0578 & -1.686 \\
$D_{3}$ & -0.025 & -0.618 \\
$D_{4}$ & $-0.257 * * *$ & -8.870 \\
$D_{5}$ & $-0.216^{* * *}$ & -8.750 \\
$D_{6}$ & -0.039 & -1.295 \\
$D_{7}$ & $0.319^{* * *}$ & 9.217 \\
$D_{8}$ & -0.014 & -0.444 \\
$D_{9}$ & $-0.156^{* * *}$ & -6.590 \\
$D_{10}$ & -0.006 & -0.230 \\
$D_{11}$ & $0.084^{* * *}$ & 2.756 \\
$D_{12}$ & $0.210^{* * *}$ & 8.025 \\
Variance Equation & & \\
C & $0.0082^{* * *}$ & 4.826 \\
ARCH(-1) & $0.5731^{* * *}$ & 5.475 \\
GARCH(-1) & $0.1076^{* * *}$ & 3.341 \\
WAR & $0.1128^{* * *}$ & 4.376 \\
$R^{2}$ & 0.891280 & \\
Adjusted $R^{2}$ & 0.876702 & \\
SE of regression & 4371.515 & \\
AIC & 18.440 & \\
SIC & 1986285 & \\
Durbin-Watson stat & 1.978023 & \\
\hline
\end{tabular}

Source: Authors' calculations.

$* * p<0.05$. *** $p<0.01$.

it shows a negative impact in explaining the tourist arrivals in Sri Lanka.

A significant seasonal effect is evident in data of tourist arrivals to Sri Lanka. Significant seasonal dummy variables with negative coefficients for April, May, and September showed that there was a decline in tourist arrivals in these months compared to months without seasonal variation. Peak levels of tourist arrivals are observed in November to January. An arguable reason for this result is the seasonal variations in those countries that generate the majority of Sri Lankan tourism, mainly European countries in the Northern Hemisphere. Their winter weather begins in November and ends in March, the same times in which Asian countries attract more tourists from Northern Hemisphere countries. This will apply to Sri Lanka too and, therefore, months from November to March can be considered as peak months with positive impacts in terms of tourist arrivals to Sri Lanka. The respective dummy variables in these months are significant at the 5\% level and they do, as expected, having a positive 
sign. Apart from a minipeak in tourist arrivals in July and August due to the cultural pageant in the Hill Capital of Sri Lanka, Kandy, months from April to September can be considered as a season with low tourist arrivals.

The GARCH $(1,1)$ parameters in the conditional variance model are stable in both high and low seasons because their sum is less than one and because the volatility shows a dampening pattern. The coefficients on the lagged squared residuals $\varepsilon_{t-1}^{2}, \sigma_{t-1}^{2}$, and WAR are significant at the $1 \%$ level in both cases. The ARCH effect, which is captured by the coefficient $\alpha$, explains short-term persistence of shocks on tourist arrivals, whereas GARCH $\beta$ captures long-run persistence. The ultimate impact on the prevalence of volatility in the long run depends on the magnitude of $\alpha+\beta$. The coefficient $\alpha$ is equal to 0.5731 , whereas $\beta$ is 0.1076 , and the sum of all three $\alpha+\beta+\varphi$ is 0.7935 . A comparison of two coefficients indicates that the ARCH effect is stronger than the GARCH effect, implying that events that shock the tourism demand have a very strong shortrun effect. Further, the sum of coefficients $\alpha+\beta+\varphi$ is less than 1 , which implies that a particular shock on tourism demand has only temporary effects on the growth rate of tourism demand. In other words, the impact of deceasing tourism demand upon exhausting the negative shock will only be quite short, and if nothing happened thereafter, it would restore the previous velocity. Because there was a sequence of events that innovate shocks including war, tourism demand remained highly volatile until 2009. The negative impact of these recurrent incidences of war have had the effect of bringing the tourist industry to a critically low performing level compared to that of the other countries in the region. Given this, the policy implications of empirical results of the GARCH estimate highlight the importance of uncertainty on the regularity of monthly tourist arrivals. The impact of the war-related incidents that have taken place in Sri Lanka, were strong enough to create considerable uncertainty that has been captured by the volatility of the model.

\section{Conclusion and Policy Implications}

Promoting tourism and tourism planning have become an important element of the postwar development strategy in Sri Lanka. International tourism has become an important source of foreign exchange earnings and the Sri Lankan government is planning to use tourism as an engine of economic growth for creating employment opportunities in its postwar development strategy. In this study, data on monthly tourism arrivals to Sri Lanka were used to model volatility of tourist arrivals for the first time in the case of Sri Lanka. As generally accepted, and in common with many other tourist destinations, the empirical results of this study demonstrate that the Sri Lankan tourism industry is very sensitive to political violence, exchange rate changes, and seasonal variations. Our analysis suggests that significant increase in political violence lowered tourist arrivals in Sri Lanka and created a substantial amount of volatility in tourism demand. As suggested by some studies considering experience in other countries, for example, Sri Lankan tourism has recovered rapidly immediately after the end of war in May 2009. With the introduction of TDS 2011-2016, the Sri Lankan government expects international tourism to play a pivotal role in postwar inclusive development. Although the country had the opportunity to become a tourism country like Singapore, it missed opportunities mainly due to the separatist war and political violence from the early 1980s to 2009.

As noted in the Introduction, volatility in tourist arrivals created by political violence affects public and private sector decision making and planning in the tourism sector. The Sri Lankan case study supports this view. For example, the Sri Lankan hotel and accommodation sector has not been able to cater to the sudden influx of tourists after the end of war due to the private sector not making the decision to invest in tourism during the war. This has led to an increase in accommodation cost in Sri Lanka, and the Sri Lankan tourism sector has become less competitive in comparison with other tourist destinations.

A few lessons and policy implications can be drawn from this case study. First, it is important to maintain peace, stability, and law and order in Sri Lanka if the government wants to achieve the targets set in its TDS. Our results clearly demonstrate that avoiding political violence and wars is an essential component of tourism development and promotion strategy and attracting increasing number of tourists to Sri Lanka. The results of this study demonstrate that political violence and war are strong enough to reduce the tourist arrival by 
$5.2 \%$ compared with the tourism price index, which is not statistically significant in explaining the tourist arrivals in Sri Lanka. Some observers believe that there is a growing number of crimes in Sri Lanka in recent months. Ruling party politicians, both at national and provisional levels, are allegedly involved in some of these crimes (particularly in December 2010 and 2011) although there has been overall peace in the country since May 2009. As such, the British government has recently issued a travel warning in August 2012 with relation to this recent surge of crime. From the Sri Lankan government's viewpoint this has been a surprise move. Our analysis, however, demonstrates that it is important for Sri Lanka to avoid this type of postwar travel warnings from western countries.

Second, it is very important to monitor the volatility of monthly tourist arrival data and manage the sector in an appropriate way to create a dynamic tourism sector in Sri Lanka. To achieve the expected tourist arrival target of 2.5 million by 2016, there should be around $2 \%$ increase in monthly tourist arrivals according to our results. Under a peaceful environment this is not a difficult task. However, it is important to attract investment in tourism-related infrastructure and hotels in order to achieve TDS targets such as doubling hotel room capacity and increased tourism-related employment.

On the basis of the results of this study and the above-mentioned lessons to be learned, a number of policy recommendations can also be made in this concluding section. First, the Sri Lankan government needs to implement measures toward reconciliation and devolution of power using a home-grown model or following a model of another country. Such measures are necessary to create a long-term political stability and to avoid another wave of political violence and wars. Second, as mentioned above, the Sri Lankan government must maintain law and order to convince international tourists that they are safe in Sri Lanka like in Singapore and other Southeast Asian competing countries. This is very important in terms of avoiding travel warnings by Western countries that are still the main sources of tourist arrivals. Finally, the tourism authorities in Sri Lanka need to implement marketing strategies to attract tourists during traditional off-seasonal months. Our model and data have demonstrated that a significant seasonal effect remains in tourist arrivals to Sri Lanka. There is a decline in tourist arrivals in some months such as April, May, and September, as Sri Lanka is not attractive to Northern Hemisphere visitors, perhaps due to rainy weather conditions in the southern part of the country. Therefore, it can be recommended that the country promote the eastern and northern parts of the country during those months and attract tourists from nontraditional sources like Australia and Southeast Asian countries.

\section{References}

Abeyratne, S. (2004). Economic roots of political conflict: The case of Sri Lanka. World Economy, 27(8), 1295-1314.

Bandara, J. S. (1997). The impact of the civil war on tourism and the regional economy [Special issue]. South Asia, 20, 269-279.

Bhanugopan, R. (2001). Tourism development in Papua New Guinea: Strategies for success. Asia Pacific Journal of Tourism Research, 6(2), 65-73.

Bollerslev, T. (1986). Generalized autoregressive conditional heteroskedasticity. Journal of Econometrics, 31, 307-327.

Chan, F., Lim, C., \& McAleer M. (2005) Modelling multivariate international tourism demand and volatility. Tourism Management, 26, 459-471.

Chang, C.-L., McAleer, M., \& Slottje, D. J. (2009). Modelling international tourist arrivals and volatility: An application to Taiwan. In B. H. Baltagi, E. Sadka (Series Eds.), \& D. Slottje (Vol. Ed.), Contributions to economic analysis: Vol. 288. Quantifying consumer preferences (chap. 11, pp. 299-315). Bingley, UK: Emerald Group Publishing.

De Mello, M., Pack, A., \& Sinclair, M. T. (2002). A system of equations model of UK tourism demand in neighbouring countries. Applied Economics, 34, 509-521.

Engle, R. F. (1982). Autoregressive conditional heteroscedasticity with estimates of the variance of United Kingdom inflation. Econometrica, 50(4), 987-1007

Divino, J. A., \& McAleer, M. J. (2008). Modelling sustainable international tourism demand to the Brazilian Amazon (Report EI 2008-22). Rotterdam, Netherlands: Erasmus University Rotterdam, Econometric Institute.

Fernando, S., Bandara, J. S., \& Smith, C. (2012). Regaining missed opportunities: The role of tourism in post-war development in Sri Lanka. Asia Pacific Journal of Tourism Research, 1-27. DOI: 10.1080/10941665.2012.695284

Gamage, A. (1978). Tourism in the economy of Sri Lanka. Unpublished masters thesis, Scottish Hotel School, Glasgow, Scotland.

Gamage, A., Shaw, R. N., \& Ihalanayake, R. (1997). The cost of political upheaval to international tourism in Sri Lanka. Asia Pacific Journal of Tourism Research, 2(1), 75-87.

Hitchcock, M., King, V. T., \& Parnwell, M. J. G. (1993). Introduction. In M. Hitchcock, V. T. King, \& M. J. G. Parnwell (Eds.), Tourism in Southeast Asia (pp. 2-6). London: Routledge. 
Hoti, S., Leon, C., \& McAleer, M. (2005). International tourism demand and volatility models for the Canary Islands. School of Economics and Commerce, University of Western Australia, Crawley.

Hylleberg, S., Engle, R. F., Granger, C. W. J., \& Yoo, B. S. (1990). Seasonal integration and cointegration. Journal of Econometrics, 44(1), 215-238.

McAleer, M., \& Divino, J. A. (2008). Modelling the growth and volatility in daily international mass tourism to Peru. Unpublished paper, Department of Economics, Catholic University of Brasilia, Brazil.

Ministry of Economic Development. (2011). Tourism Development Strategy 2011-2016. Colombo, Sri Lanka: Author.

Murdoch, S. J., \& Sandler, T. (2002). Civil wars and economic growth: a regional comparison. Defence and Feace Economics, 13(6), 451-464.

Neumayer, E. (2004). The impact of political violence on tourism. Journal of Conflict Resolution, 48(2), 259-281.

O’Hare, G., \& Barrett, H. (1994). Effects of market fluctuations on the sri lankan tourist industry: Resilience and change, 1981-1991. Tijdschrift voor economische en sociale geografie, 85(1), 39-52.

Pizam, A., \& Mansfeld, Y. (1996). Tourism, crime and international security issues. Chichester, UK: Wiley.

Selvanathan, S. (2006). The effect of war and other factors on Sri Lankan tourism. Applied Economics Letters, 14(1), 35-38.

Sergo, Z., Poropat, A., \& Grzinic, J. (2010). Tourism demand and GARCH models for Croatia. In Proceedings of the 20th Biennial International Tourism \& Hospitality Industry 2010: New Trends in Tourism and Hospitality Management (pp. 599-615). Opatija, Croatia: Faculty of Tourism and Hospitality Management.

Sergo, Z., Tomcic, A., \& Poropat, A. (2005). Models of overnights from tourism demand in Croatia 1960-98 In Sixth International Conference on Enterprise in Transition Proceedings (pp. 1319-1340).

Sevil, F. S. (1998). Tourism, terrorism, and political instability. Annals of Tourism Research, 25(2), 416-456.
Shareef, R., \& McAleer, M. (2005). Modelling international tourism demand and volatility in small island tourism economics. International Journal of Tourism Research, 7(6), 313-333.

Shareef, R., \& McAleer, M. (2007). Modelling the uncertainty in monthly international tourist arrivals to the Maldives. Tourism Management, 28(1), 23-45.

Shareef, R., \& McAleer, M. (2008). Modelling international tourism demand and uncertainty in Maldives and Seychelles: A portfolio approach. Mathematics and Computers in Simulation, 78(2), 459-468.

Sinclair, R. M., \& Stabler, M. (1997). The economics of tourism. London: Routledge Taylor Francis Group.

Sri Lanka Tourism Development Authority. (2010). Annual statistical report of Sri Lanka tourism-2010. Colombo, Sri Lanka: Author.

Song, H., \& Li, G. (2008). Tourism demand modelling and forecasting-A review of recent research. Tourism Management, 29, 203-220.

Song, H., \& Witt, S. F. (1999). Tourism demand modeling and forecasting. Modern econometric approaches. Amsterdam: Elsevier.

Syriopoulos, T. C., \& Sinclair, M. T. (1993). An econometric study of tourism demand: The aids model of US and European tourism in Mediterranean countries. Applied Economics, 25, 1541-1552.

Tisdell, C. A., \& Bandara, R. R. (2005). Tourism and economic development in Sri Lanka (1st ed., Vol. 1). New Delhi, India: Serial Publications.

White, K. J. (1985). An international travel demand model US travel to Western Europe. Annals of Tourism Research 12, 529-545.

Wickremasinghe, G. B., \& Ihalanayake, R. (2006). The causal relationship between tourism and economic growth in Sri Lanka: Some empirical evidence (Working paper WP2006.10). Melbourne, Australia: School of Applied Economics, Victoria University. 